\title{
Berislav Majhut
}

Sveučilište u Zagrebu, Učiteljski fakultet - Odsjek u Petrinji

bmajhut@gmail.com

\section{0 godina u studentskim indeksima: prvi hrvatski kolegij o dječjoj književnosti}

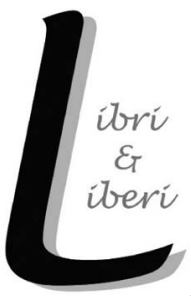

Izučavanje književnih postupaka u dječjoj književnosti kao i prikaza povijesti hrvatske dječje književnosti postoji u Hrvatskoj već od kraja 19. stoljeća. Svijest, pak, o potrebi nastave dječje književnosti koja bi se temeljila na rezultatima tih istraživanja probijala se vrlo polako, prije svega na ustanovama koje su se bavile obrazovanjem budućih učitelja, te se pojavila tek nakon 2. svjetskog rata. Prvi kolegij koji se bavio temom dječje književnosti u toj mjeri da je termin 'dječja književnost' bio uključen i u naziv kolegija je Kultura usmenog i pismenog izraza s dječjom literaturom $i$ vrlo je vjerojatno da se po prvi puta mogao čuti na katedrama hrvatskih pedagoških akademija u jesen 1961.

Ključne riječi: kolegij dječje književnosti, hrvatska dječja književnost, studiranje dječje književnosti, učenje dječje književnosti, učitelji $i$ dječja književnost

Cilj je ovoga rada ustanoviti kada i gdje se prvi puta pojavio akademski interes za izučavanje dječje književnosti u Hrvatskoj.

Može se pretpostaviti kako se zanimanje za istraživanje dječje književnosti po prvi puta pojavilo u okviru obrazovanja učitelja. Učitelji posreduju svojim učenicima književnost koja je usmeno ili pismeno namijenjena djeci. Neminovno je da se u jednom trenutku postave pitanja o naravi i povijesti takve književnosti. To je začetak, iskra istraživačkog zanimanja za predmet dječje književnosti iz koje se morala roditi želja da se ta građa istraži, obradi i usustavi. Prvi teorijski tekstovi o naravi dječje književnosti pod jakim su utjecajem njemačkih autora i javljaju se već osamdesetih godina 19. stoljeća, ${ }^{1}$ dok je prvi prikaz povijesti hrvatske dječje književnosti onaj Stjepana Širole iz 1896. pod naslovom „Naša omladinska

\footnotetext{
Primjerice Ivan Filipović (1885) ili Jelica Belović Bernadzikowska (1897).
} 
književnost““. Prvi istraživači koji se u nas bave dječjom književnošću su, dakle, učitelji.

Peter Hollindale, prikazujući 1998. mjesto suvremenog izučavanja dječje književnosti u Velikoj Britaniji kaže da se u posljednjih tridesetak godina otvorilo široko polje akademskom bavljenju dječjom književnošću u okviru English Studies, tj. u okviru odsjeka za engleski jezik i književnost, te je izašlo iz okrilja ,institucija za izobrazbu učitelja“" (43):

Postupno izranjanje dječje književnosti kao akademskog područja u posljednjih pedesetak godina nije slučajno događanje. [...] Do 1950-tih proučavanje dječjih knjiga bilo je praktički ograničeno na institucije za izobrazbu učitelja, te je predstavljalo sporedan dio uporabnog znanja struke učitelja engleskoga.

Za razliku od britanske situacije, u hrvatskim prilikama proučavanje dječje književnosti i dan danas se svojim najvećim dijelom nalazi u okvirima učiteljskih fakulteta. ${ }^{2}$ Upravo ta okolnost i nameće smjer detektiranja i traganja za prvim oblicima te razvoj akademskog zanimanja za dječju književnost prema institucijama koje su se bavile izobrazbom učitelja.

\section{Devetnaesto stoljeće}

Prema uredbi koja je stupila na snagu 1857. dvogodišnje preparandije u Zagrebu i Đakovu imaju sljedeće „redovite učevne predmete“ (Modec 1885: 32):

a) nauk vjere sa bibl. poviešću;

b) uzgojo- i obukoslovje;

c) jezična obuka t. j. obuka u čitanju uz slovnicu, pravopis i pismene sastavke;

d) računstvo;

e) kraso- i brzopis;

f) risanje i geometrija;

g) pjevanje i orguljanje;

h) poljsko gospodarstvo.

U sklopu predmeta ,jezična obuka“ ili, kako stoji u svjedodžbi, Jezik ilirski kao jezik obučavanja uopće se nisu predavali književni sadržaji. Kada se govori o sadržajima tog predmeta, pa i kad se upućuje kako valja rabiti čitanke, napominje se sljedeće (34):

Kod upućivanja, kako valja rabiti čitanke, naći će valjan preparandijalni učitelj dosta prilika, da iz pojedinih predmeta, kao: iz domoslovja, prirodopisa, i prirodoslovja ono, što je upravo najpotrebnije da se znade, sa pripravnici stranom ponovi, stranom im priobći, kod čega znat će ih i uputiti, kako će to u pučkoj školi morati upotrebiti.

2 Tome je tako premda se doktorati s temama iz dječje književnosti redovito brane na Kroatistici. Barem je takav slučaj na najvećem hrvatskom sveučilištu, onome u Zagrebu. 
Čitanke za pučke škole su imale enciklopedijsku, a ne književnu građu pa se onda niti u metodici rada s čitankom nije pojavljivala potreba za elaboriranjem književnih sadržaja. Takve je čitanke, s 'realnom građom', 1851. za škole u Austrijskoj carevini izdao Theodor Vernaleken, a prepravili su ih, za hrvatske prilike, Ivan Filipović i Matija Mesić (članak „Čitanka“ u Pedagogijskoj enciklopediji, 1895-1906).

Tek između 1876. i 1880. Hrvatski pedagoško-književni zbor izdao je nove čitanke koje su predstavljale svojevrsni kompromis između zahtjeva za 'stvarnom obukom' i realističnim štivom te, s druge strane, književnih sadržaja.

Mažuranićev zakon o školstvu iz 1874. izravno je utjecao i na ustrojstvo preparandija. I u muškoj i u ženskoj trogodišnjoj preparandiji predmet s najvećim brojem sati bio je Hrvatski jezik i poviest književnosti njegove. Nastavni program ili 'naukovna osnova' bio je isti i na muškoj i na ženskoj preparandiji, kao što prenosi Modec (1885: 34):

$\mathrm{Z}$ a d a ć a. Dovoljno znanje slovnice i skladnje. Razgovjetno i pravilno govorenje, okretno ustmeno predavanje iz svih učevnih predmeta; pravilno, točno i pregledno pisanje, poznavanje tehnike glavnih vrsti prozaičkih i pjesničkih umotvorina, i poznavanje najznamenitijih proizvoda književnosti srednjega i novoga doba.

I. tečaj. Slovnica: najglavnije o glasoslovju, o oblicih i o tvorenju rieči: zatim skladnja slaganja i djelovanja, i to imenih. (2 ure.)

Čitanje: vježbanje u pravilnom, umnom i blagoglasnom čitanju, u pripoviedanju, kazivanju sadržaja i poredanja misli u čitanih štivih, u predavanju. (2 ure.)

Stilistika: Nauk o prozi i glavnih vrstih prozaičkih umotvorina, osobito o pripoviedci, opisu, listu i znamenitijih poslovnih sastavcih po danih osnovah, i vježbanje u izradjivanju osnova po čitanih štivih. (2 ure)

Svake dvie nedjelje 1 školska i 1 domaća zadaća.

II. Tečaj. Slovnica: Skladnja djelovanja počam od glagolja. Skladnja poredanja. Specijalna metodika slovničke obuke. (2 ure.)

Čitanje: Vježbanje u čitanju i razlaganju štiva po sadržaju i obliku. Vježbanje u slobodnom predavanju.

Stilistika: Nauk o pjesničtvu i o glavnih vrstih pjesničkih umotvorina. Nastavak u pismenih vježbah I. tečaja; pretvaranje pjesničkih štiva u prozaička, izradjivanje potanjih osnova čitanih pjesničkih umotvorina. (2 ure.)

Svakog mjeseca po 1 domaća i 1 školska zadaća.

III. Tečaj. Uputa u porabu čitanke u obće, a napose u pučkoj i gradjanskoj školi rabljenih čitanka. (1 ura.)

Pregled književne poviesti, a osobito srednjega i novoga doba. (2 ure.)

Stilistika: O razpravah i govorničtvu. Izradjivanje razprava osobito pedagogijskih po danih i po samostalno izradjenih osnovah. (1 ura.)

Svakoga mjeseca 1 domaća i 1 školska zadaća.

U „Naučnim osnovama“ za Učiteljske četverogodišnje škole koje se provode od 1888. za predmet Hrvatski ili srbski jezik se navodi (Ustrojni Štatut za učiteljske škole u Kraljevinah Hrvatskoj i Slavoniji 1889: 13-14): 
Zadaća. Dovoljno poznavanje slovnice i skladnje. Razgovjetno i pravilno izkazivanje misli usmeno i pismeno. Poznavanje glavnih vrsti prozajičkih i pjesničkih oblika. Poznavanje najznamenitijih proizvoda književnosti, naročito srednjega i novoga doba.

Što se tiče književnosti, o njoj se, u nastavnom programu predmeta, govori tek u trećem tečaju (14):

b) Čitanje. Usavršavanje u čitanju i razlaganju štiva po sadržaju i obliku, a s tim u savezu upoznaja s najznamenitijimi proizvodi literature te životom i radom najznamenitijih književnika.

I u četvrtom tečaju (15):

b) Čitanje glavnih djela iz hrvatske i srbske književnosti. Pregled književne poviesti, osobito srednjega i novoga doba.

Dakle, jedini sadržaji iz književnosti s kojima se susreću polaznici Učiteljske škole su djela iz književnosti za odrasle. Treba primijetiti da se uvijek govori o književnosti „srednjeg i novog doba“ dok je antička književnost predmetom obrazovanja u gimnazijama, dakle, predaje se onim učenicima iz čijih redova će se regrutirati polaznici sveučilišta.

Krajem 19. stoljeća čitanke u Hrvatskoj (u sklopu Austro-Ugarske Monarhije do 1918.) uglavnom sadrže književnu građu pa se javlja pitanje kako tu književnu građu prezentirati učenicima. Izvan sustava formalnog obrazovanja pojavljuju se knjige koje pomažu gotovim učiteljima kako što lakše i učinkovitije postići taj cilj, to jest omogućiti učenicima shvaćanje književne građe prezentirane u čitankama.

Milan Kobali je 1893. priredio Rukovođ za estetičko-etična štiva u pučkoj školi: prema formalnim stupnjevima ${ }^{3}$ u nakladničkoj cjelini Knjižnica za učitelje. Knjiga je 1897. prevedena i na bugarski. U „Uvodu“ Kobali kaže (ix-x):

Premda učitelj, kadgođ obučava, ujedno i uzgaja, jer ima kod svakoga prijedmeta zgode, da u mladeži, povjerenoj njegovoj brizi, pobudi smisao za različite kreposti; to ipak ima u čitankama, za pučke škole posebnih estetično-etičkih štiva, koje valja posebice obrađivati, i kojima se osobito može da pobudi smisao za različite kreposti. [...] Mladež, u kojoj je pobuđen smisao za različne kreposti, kao što su strah božji, domoljublje, radljivost, štedljivost, milosrđe itd. prisvojila je sebi najveće blago; jer je pomenute kreposti čine značajnom. [...]

Spomenuvši čemu su pripovijetke i pjesme u čitankama, prelazimo odmah na to, kako ih valja obraditi prema formalnim stupnjevima.

U cijelji treba da učitelj istakne ideju, koja je podlogom štivu, kako bi to djeca mogla razumjeti i kako da se sva pozornost njihova na to svrati.

Dalje Kobali pokazuje kako se kroz pet formalnih metodičkih stupnjeva mogu

\footnotetext{
3 Pet Herbart-Zillerovih metodičkih formalnih stupnjeva: analiza, sinteza, asocijacija, sustav, metoda.
} 
koristiti dvije metode obučavanja: razvijanje i ispitivanje. ${ }^{4}$ Te formalne metodičke stupnjeve Kobali primjenjuje na štiva ovako (1893: x-xv):

$\mathrm{Na}$ I. stupnju neka nastoji učitelj, da se djeca zamisle u sličnu situaciju, o kojoj se poglavito govori u štivu. Tako će se u njoj razviti ono čuvstvo, koje je potrebno, da sadržaj štiva, s kojim će ih on upoznati, uzmože što jače djelovati ne samo na um, nego i na srce njihovo. [...analiza...]

Na II. stupnju: a) Pripovijeda učitelj dotično štivo svojim riječima. Za njim pripovjedaju štivo najprije najbolji, a onda ostali učenici, u koliko je to potrebno. [...] b) Učitelj čita sam dotično štivo, da djeca slušajući njega, priviknu lijepom i valjanom čitanju. [...] c) Pročitavši štivo, protumači im učitelj manje poznate riječi i izraze, no tu se ne smije učitelj upuštati u stvarno ili jezično tumačenje. [...] d) Neka se djeca ponukaju, da kažu, što sude o licima i njihovim mislima, o kojima se govorilo u dotičnom štivu; da reknu, kako im se sviđaju njihovi činovi. [...sinteza...]

$\mathrm{Na}$ III. stupnju ispoređuje se dogođaj, čini ili misli sa drugim srodnim, koji su učenicima poznate iz drugog kojeg štiva ili poznate biblijske ili svjetske pripovijetke, a navlastito narodne. [...asocijacija...]

$\mathrm{Na}$ IV. stupnju izvede se ćudoredno pravilo u obliku mudrih rečenica, narodnih poslovica, citatima iz sv. pisma ili kojega pjesničkoga djela. Da ta ćudoredna pravila učenici upamte, dobro je, da ih ponavljaju u zboru, navlastito u prvom i drugom razredu. A mogu se one mudre rečenice ili poslovice i napisati.

Pjesme epskog sadržaja valja obraditi kao i pripovijetke. Sadržaj pripovijeda učitelj svojim riječima, pa se pjesma čita na odlomke ili razjašnjavaju manje poznate riječi itd. ispoređuje se sa sadržajem druge poznate pjesme ili pripovijetke i izvede ćudoredna pouka. - I lirske pjesme se tako obrade samo s tom razlikom, da se sadržaj ne pripovijeda svojim riječima, nego je učitelj deklamuje ili uzorno pročita, a mjesto ćudoredne pouke, istakne se glavna misao pjesme. [...sustav...]

$\mathrm{Na}$ V. stupnju primjenjuje se izvedeno ćudoredno pravilo ili pouka na pojedine prilike života. [...metoda...]

Dakle, Kobali se ograničava na štiva u čitankama. Njegov Rukovođ pomoć je učiteljima u nastavi, a nije dio njihovoga formalnoga obrazovanja. U sustavu učiteljskoga obrazovanja budući učitelji uče književnost kroz povijesni razvoj, a ne susreću se s metodikom štiva namijenjenog djeci, pa makar i samo onog $\mathrm{u}$ čitankama.

\section{9.-1934.}

U naučnoj osnovi Više pedagoške škole u Zagrebu, ${ }^{5}$ koja je osnovana 1919.

${ }^{4}$ „Neki zagovaraju razvijajući oblik, gdje učitelj više govori, a učenici ponavljaju, a drugi ispitujući, gdje učitelj zgodnim pitanjima nastoji, da mu djeca sama kažu ono, što su vidjela i iskusila“" (Kobali 1893: x).

5 Pohađali su je završeni polaznici četverogodišnje (a prema Zakonu o Učiteljskim školama iz 1929. petogodišnje) Učiteljske škole. 
kao prva u državi ${ }^{6}$ (sljedeće godine osnovana je i u Beogradu), razdvojeni su kolegij Narodni jezik (sa starim slovenskim) ${ }^{7}$ od kolegija Narodna književnost (sa seminarom). Nastavni program kolegija Narodne književnosti (u smislu umjetničke komponente Narodnog jezika, a ne usmene književnosti) u cijelosti opisan je ovako (Viša pedagoška škola u Zagrebu, 1934: 41):

Narodna književnost (sa seminarom)

Izabrana poglavlja iz teorije književnosti. Pregled narodne književnosti. Pregled književnosti srednjega vijeka. Književnost od XV vijeka do najnovijega vremena.

U seminaru: Čitanje i tumačenje tekstova, čitanje radnja i diskusija o njima.

Dakle, unutar književnosti nigdje se ne prepoznaje dječja književnost.

\section{1.}

Prema Privremenom nastavnom planu iz 1931. za učiteljske škole u čitavoj Kraljevini Jugoslaviji, Narodni jezik od svih predmeta ima najveću satnicu: u prva dva razreda po četiri sata tjedno, a u 3., 4. i 5. razredu po tri sata tjedno. Jedan od ciljeva predmeta Narodni jezik tiče se književnosti (1931: 31):

da upozna srpskohrvatsku i slovenačku književnost od najstarijeg do najnovijeg vremena, a u vezi s tim najznačajnije pojave velikih slovenskih i svetskih književnosti.

Dakle, uopće se ne spominje pojam dječje književnosti niti se prepoznaje dječja književnost kao područje književnosti koju učitelj treba posredovati učenicima. Ovdje valja uočiti kako povijest književnosti nije više ograničena na „srednju i novu dob“, već samo na „najznačajnije pojave“ što onda uključuje i najveća djela antičke književnosti. ${ }^{8}$

U dijelu o metodici se kaže (10-11):

Metodika početne nastave narodnog jezika, veronauke, istorije, crtanja, pevanja, gimnastike: 1) zadatak i važnost svakoga od ovih nastavnih predmeta u narodnoj školi s kratkim istorijskim pogledom na razvitak nastave toga predmeta; 2) izbor i raspored nastavnog gradiva prema opštim vaspitnim i nastavnim načelima i prema prirodi pojedinih nastavnih predmeta; 3) obrada nastavnog gradiva iz svakoga predmeta ponaosob.

${ }^{6}$ Hrvatska je 1918.-1929. u sklopu Kraljevine Srba, Hrvata i Slovenaca. 1929. Kraljevina SHS mijenja naziv u Kraljevinu Jugoslaviju (1929.-1941.)

7 Na prvoj godini predmete Gramatiku narodnoga jezika (2 sata) i Oblike jezika staroga slovenskoga (misli se staroslavenskog) (1 sat) te na drugoj godini Gramatiku narodnoga jezika (3 sata) predavao je dr. Milan Strašek. Narodnu književnost sa seminarom (i na prvoj i na drugoj godini 5 sati) predavao je dr. Mihovil Kombol.

8 Tako je u prvom razredu predviđeno da se na satu obrađuju po četiri pjevanja iz Ilijade, Odiseje i Eneide (a ostatak je bio lektira kod kuće). U drugom razredu čitali su djela Eshila, Sofokla, Euripida i Aristofana (Privremeni nastavni plan i program 1931: 33). 
Kako se to misli, da će metodikom Narodnog jezika budući učitelji naučiti kako će djecu-učenike poučavati književnost na primjerima, recimo, Eshila i Krleže, nije objašnjeno.

\section{1.-1945.}

Za Nezavisne Države Hrvatske (1941.-1945.) u Učiteljskim školama jednostavno se izostavio dio sadržaja predmeta te uveo korienski pravopis (Službeni glasnik Ministarstva nastave, 1941: 680):

U obuci hrvatskog jezika i književnosti izostavlja se ćirilica, te srpska i slovenska književnost. Kako su školske knjige za ovu školsku godinu tiskane prema ministarskoj naredbi o hrvatskom pravopisu od 25. lipnja o. g., koja je objavljena u Narodnim novinama od 25. lipnja o. g. to hrvatski pravopis u školama treba takodjer učiti prema toj naredbi.

Književnost se ne spominje iako je studij privremeno produžen na četiri godine, a Viša pedagoška škola u Zagrebu 1941. biva podignuta na rang Visoke pedagoške škole. No nakon 2. svjetskog rata gubi opet taj status (Težak 1971: 6).

\section{6.}

Nove okolnosti ${ }^{9}$ nakon završetka 2 . svjetskog rata brzo su učinile očitim da učitelji koji odgajaju nove naraštaje moraju i sami svoja znanja i stavove podvrgnuti temeljitoj reviziji, i to prije svega ideološkoj i vrijednosnoj, jer im je znanje „neispravno pa ga treba ispraviti“, a tek potom i nedostatno pa ga „treba prema razvoju nauke dopuniti“. Upravo u tom nadopunjavanju učiteljskog znanja po prvi puta se pojavio i pojam „dječje književnosti“" i to u zanimljivom i indikativnom okružju (Plan i program za stručno usavršavanje nastavnika, 1946: 1):

Prvi kongres Saveza prosvetnih radnika stavio je u dužnost: 1) da Centralna uprava Saveza, u sporazumu sa prosvetnim vlastima, organizuje političko i stručno usavršavanje svojih članova, što će se obezbediti izborom specijalnih komisija pri Centralnoj upravi i Zemaljskim odborima Saveza; 2) da Centralna uprava izradi okvirni program za stručno usavršavanje i političko uzdizanje svojih članova.

Komisija za stručno usavršavanje učitelja i nastavnika opšte obrazovnih škola, koja je formirana pri Centralnoj upravi Saveza, konsultujući se sa širokim krugom učitelja i nastavnika - teoretičara i praktičara - sastavila predloženi plan i program. Program je sastavljen u suglasnosti s prosvetnim vlastima. [...]

Program ima dva dela i to:

1) Za učitelje osnovnih škola; i

9 Hrvatska je 1945.-1963. u sklopu Federativne Narodne Republike Jugoslavije. 1963. FNRJ mijenja naziv pa je Socijalistička Republika Hrvatska od 1963. do 1991. jedna od republika Socijalističke Federativne Republike Jugoslavije. 
2) Za nastavnike srednjih opšteobrazovnih škola. [...]

Prvi i drugi deo programa se deli na:

a) Okvirni program za stručno usavršavanje iz područja pedagogike, psihologije, didaktike i metodike. [...]

b) Okvirni program za stručno usavršavanje nastavnika iz područja nastavne građe koja je propisana nastavnim programom za osnovne škola, odnosno pojedine struke srednjih opšteobrazovnih škola. Računajući sa činjenicom da je dobiveno znanje u učiteljskim školama, odnosno na univerzitetima ili nepotpuno, pa ga treba prema razvoju nauke dopuniti, ili je bilo neispravno pa ga treba ispraviti. Komisija je na osnovu toga izabrala najaktuelnije teme iz pojedinih oblasti nauke.

Stručno će se usavršavati učitelji i nastavnici okupljeni u 'sindikalne grupe' odnosno 'radne aktive' koji će se sastajati jednom tjedno tijekom školske godine pa će se stići obraditi između 24 i 28 tema.

U okviru dijela namijenjenog učiteljima (dakle ,1) $)^{\text {“ }} \mathrm{u}$ gornjem citatu), i to „Okvirnog programa za stručno usavršavanje iz područja pedagogike, psihologije, didaktike i metodike“" kao sedma točka (od ukupno njih osam) predviđena je sljedeća tema (Plan i program 1946: 3):

\section{„Šta treba da znam o dečjoj literaturi?““}

Građa z a t e m u : 1), Metodika čitanja dečje literature“, Čehov, prevod sa ruskog.

2) „Šta treba da znam o dečjoj literaturi“, referat će izraditi Komisija pri Centralnoj upravi Saveza. [Isticanja u izvorniku, op. B. M.]

Očito je da je stvorena svijest o potrebi nadogradnje postojećeg obrazovanja učitelja i o temi dječje književnosti. Također je vidljivo da se radi zapravo o posve novom području koje je, za razliku od prethodnih tema, još neraščlanjeno i za koje niti ne postoji literatura, pa se moraju uzimati strani prijevodi te tek izrađivati referati. Strana literatura (Čehov) će naravno pokazati ideološki kut iz kojeg se ima obrađivati ta tema, a primjenu na specifičnu jugoslavensku situaciju dat će referat.

Nedostatak znanja o dječjoj književnosti uočen je, dakle, samo kod učitelja i to u okviru metodike. Svijesti da bi bilo potrebno nadograditi i znanje predmetnih nastavnika (dakle, onih koji će predavati u nižim razredima gimnazije ili višim razredima osnovne škole) o dječjoj književnosti - nema. Nema je također niti u dijelu o nastavnoj građi, već samo u okviru metodike.

Možda bi ovdje bilo potrebno načiniti digresiju. Ne radi se samo o tome da je konačno sazrela svijest da se učitelji trebaju početi baviti književnošću koja je namijenjena specifičnoj dobi njihovih učenika. Više od toga je u igri. Došlo je 'novo doba'. Malo toga se može preuzeti od naslijeđene 'buržujske književnosti'. Malo će toga ostati na policama knjižara kad se očiste od balasta, novim uvjetima neprihvatljive, građanske književnosti. A praznine treba popuniti novom književnošću. Za tu novu književnost, koje još faktički nema, već su predviđeni društveni zadaci koje ona treba ostvariti, već se unaprijed zna o čemu ona mora 
govoriti i kojim se temama mora baviti. I učitelji se trebaju osposobiti da bi se na primjeren način bavili dječjom književnošću i da bi je s djecom obrađivali na primjeren način: djecu ne treba poučavati nasljeđu povijesti, vrijednostima tradicije već, upravo suprotno, treba ih osloboditi tog mučnog tereta povijesti.

U knjižici Dajte deci literaturu! objavljenoj u Beogradu 1945. Maksim Gorki piše (Gorki, Beljajev i Tauber 1945: 11-12):

Pitanje tema dečjih knjiga je pitanje pravca socijalnog vaspitanja dece. U našoj zemlji vaspitavati znači revolucionisati, tj. oslobađati mišljenje deteta od tehničkih navika mišljenja utvrđenih prošlošću, od zabluda u mišljenju, u čijoj je osnovi naslagano mnogovekovno iskustvo konzervativnog života, zasnovanog na klasnoj borbi i težnji jedinki da se zaštite i utvrde individualizam i nacionalizam kao „večne forme“" i zakoni socijalnog života.

Odgajati znači revolucionarno mijenjati mišljenje djeteta u pravcu kolektivizma i internacionalizma. A to je nemoguće učiniti s književnošću naslijeđenom iz predrevolucionarnih vremena (naime, jugoslavenska narodnooslobodilačka borba 1941.-1945. imala je revolucionarni karakter). Riječi Maksima Gorkog, izvorno objavljene u Sovjetskom Savezu 1933., objavljene u Jugoslaviji 1945. i više su nego aktualne. One su istovremeno i inicijalna kapsula i plodonosna sjemenka aktualnosti. Te riječi tek treba doslovno ostvariti (Gorki 1949: 174):

Naš zadatak otežan je time što mi iz ovog buržoaskog nasleđa možemo preuzeti samo veoma malo, mnogo manje no što je preuzela književnost za odrasle: možemo preuzeti izvesna dela klasika, i dela iz raznih narodnih eposa, - pa i to u novim prevodima $\mathrm{i}$ novoj preradi $[\ldots]$

I Ljudevit Krajačić, posve na tragu Gorkoga, u radu „Omladinska knjiga i njeni današnji zadaci“ iz 1946. smatra kako je potrebno poduzeti temeljitu reviziju dječje književnosti (13):

[...] treba ubuduće omladinsku literaturu staviti pod stručnu i strogo objektivnu kontrolu kritike i ono, što ne vrijedi bezobzirno odstraniti s literarnoga tržišta, ili uopće ne dopustiti da se na njemu pojavi. S tim u vezi napominjem, da bi bilo prijeko potrebno da se učini revizija dosadašnjih edicija iz oblasti omladinske književnosti, pa da se odstrani sve što nije valjano i što nije u mogućnosti da oplemeni duševni život djeteta $u$ duhu današnjih potreba. Mnogo bi se tu našlo korova, a na taj bi se način ne samo pročistilo tržište omladinskih knjiga, nego bi se, što više, stvorila i veća mogućnost prodaji valjanih, u domovinskoj borbi nastalih ili kasnije napisanih omladinskih knjiga.

A o kakvom, točno definiranom, „oplemenjivanju duševnog života djeteta“ je riječ govori ovaj odlomak (12):

Treba dakle pri današnjem izgrađivanju omladinske književnosti imati na umu činjenicu, da se ona više nikako i nikada ne smije otuđiti narodu, postati strana narodnim osjećajima i narodnim potrebama. Ona mora biti ubuduće u isto vrijeme 
koliko narodna toliko i omladinska. Ona mora postati i izgrađivati se u pravcu da bude ogledalo herojske borbe naroda u nedalekoj prošlosti za slobodu osobnu i slobodu otadžbine; ona mora biti ubuduće evanđelje ljubavi naroda za Zemlju i propovjedaonica mržnje i prezira prema onima, koji nam zadadoše toliko boli, koji nam naniješe toliko sramote i nepravde.

Treba svakako zapaziti kako je riječ o sasvim novom tipu književnosti koja se zahtijeva za novo poslijeratno vrijeme. Književna djela više nisu one tvorevine duha koje svojim idejama jure ispred svog vremena i otvaraju nove horizonte. Tako je to bilo u građanskoj književnosti. Sada u novoj književnosti ideje i viziju novog vremena stvaraju neki drugi, izvan književnosti (komunisti kao avangarda revolucionarnih ideja prekaljenih u klasnoj borbi), a književnost mora biti takva da odgovara po njima unaprijed ocrtanim zadacima i idejama. Ako još i nema takve književnosti, ona će se nesumnjivo pojaviti, ako još i nema književnika koji je pišu, oni će se bez sumnje izroniti na površinu. Evo, čini se da se prvi takav pjesnik pojavio! To je Branko Ćopić! (Krajačić, 1946:12):

Po svemu izgleda, da naša današnja omladinska književnost još nije našla svojih pjesnika i svojih pripovjedača iako oni nesumnjivo žive u našoj sredini, oni su tu, tek čekaju svoj čas, a mi njihov dolazak. Jedan je tu, i to snažan i izgrađen talent, ranije spominjani pripovjedač i pjesnik Branko Ćopić, partizan, koji se kao pjesnik izgradio u teškoj domovinskoj borbi i koji je po svojoj unutrašnjoj izgradnji, po snazi svog pjesničkog izričaja, po osjećajnosti i po plastici svog pjevanja, a nada sve po svome prekaljenom patriotizmu, on zna što može, što hoće i što našoj omladini njena današnja književnost mora reći, što joj moraju dati njeni pravi književnici, jednako pjesnici kao pripovjedači, ako hoće da budu zaista njezini najbolji učitelji. Branko Ćopić bezuvjetno novome dobu utire sigurne putove u novu dječju literaturu i danas je on u nas njen najizrazitiji i najsnažniji interpreta. Njemu će morati podražavati mnogi možda talentirani, ali manje samonikli, manje invencioni pjesnici i pisci u oblasti omladinske književnosti, ako će htjeti da se bar kako tako osjete i zapaze u njoj i da koriste omladini i zadacima savremene omladinske književnosti.

\section{2.}

U Nastavnom programu za petogodišnju učiteljsku školu za predmet Hrvatski ili srpski jezik $i$ književnost u 1. razredu ${ }^{10}$ predviđena su sljedeća poglavlja: „I. Povijest i teorija književnosti; II. Analiza književnih djela, pismene i govorne vježbe; III. Dječja i omladinska književnost; IV. Gramatika i pravopis; V. Školski i domaći pismeni zadaci i vježbe“. Dok se, primjerice, u prvom poglavlju izlaže povijesni pregled književnosti za odrasle na gotovo dvije stranice, čitav program III. poglavlja „Dječja i omladinska književnost“ elaboriran je u ovom retku: „Narodna književnost kao dječja i omladinska književnost. Narodna i umjetna bajka.“ (Nastavni plan i program za Učiteljsku školu, 1952: 26)

\footnotetext{
${ }_{10}$ Nastavnim planom predviđena su 4 sata tjedno u svakoj od pet godina.
} 
U 2. razredu, dok se program poglavlja „Povijesti i teorije književnosti“ razlaže na cijeloj stranici, nastavna građa predviđena za poglavlje „Dječja i omladinska književnost“" izražena je još lapidarnije nego u prvom razredu, u samo pola retka: „Basna, bajka i priča o životinjama.“ (28)

I u ostalim razredima naglašen je nerazmjer unutar nastavnog programa između dijela koji se bavi „Poviješću i teorijom književnosti“ te onog njegovog dijela koji se bavi „Dječjom i omladinskom književnošću“. Tako je predviđeno da se u 3. razredu obrade ove teme iz dječje književnosti (30):

Historijski razvoj književnosti za djecu i omladinu.

Pojam dječje i omladinske književnosti, značenje te književnosti za intelektualno, moralno i estetsko odgajanje djece.

Različiti pogledi na književnost za djecu. Romantika. Idealiziranje života i stvarnosti.

A u četvrtom razredu (32):

Različiti pogledi na književnost za djecu.

Realizam.

Vrste dječje i omladinske književnosti.

Upoznavanje s dječjim slikovnicama, njihova književna i likovna vrijednost.

Upoznavanje i analiza štiva i pjesme iz čitanki za osnovne škole. Vježbe u dramatizaciji štiva i recitaciji pjesama za djecu.

U petom razredu (35):

Naši savremeni dječji i omladinski pisci. Savremeni dječji i omladinski listovi.

Upoznavanje i analiza štiva i pjesama iz čitanki za narodne škole. Vježbe u dramatizaciji štiva i recitaciji pjesama za djecu.

Dok je 1. poglavlje „Povijest i teorija književnosti“ u svih pet razreda vrlo detaljno razrađeno, što onda već opsegom pažnje poklonjene tim temama unutar nastavnog programa ne samo upućuje na važnost koju se pridaje tom dijelu predmeta, već i zadaje vremenski okvir koji će mu se posvetiti u satnici, „Dječjoj i omladinskoj književnosti“ pridaje se tek simbolična pažnja.

I u pristupu izučavanju dječje književnosti se rabe pojmovi primjereni izučavanju književnosti za odrasle: 'romantika', 'idealiziranje', 'realizam' (ti pojmovi nisu samo neutralni deskriptivni pojmovi književne povijesti već su i snažno ideološki, a onda znači i vrijednosno obojeni).

Ipak, napokon je tema dječje književnosti, makar i nesamostalno, dakle, u sklopu predmeta posvećenog književnosti, dobila svoje legitimno mjesto.

Juraj Bukša, profesor Učiteljske škole u Petrinji, 1951. piše članak „O programu iz književnosti za učiteljske škole“ nezadovoljan nastavnim programom književnosti u četverogodišnjoj učiteljskoj školi (vidjeli smo gore kako će već 1952. učiteljske škole postati petogodišnje). U njegovim primjedbama još uvijek 
se nigdje ne nazire tematika dječje književnosti. No, već 1952. Bukša objavljuje za ono doba nevjerojatno hrabar članak o počecima „naše“ dječje književnosti u kojem zapravo govori o povijesti hrvatske dječje književnosti. Suprotstavljajući se tada dominantnom mišljenju kako na početku hrvatske dječje književnosti stoje 'napredni' učitelji okupljeni oko Ivana Filipovića i Hrvatskog pedagoškoknjiževnog zbora (HPKZ), ${ }^{11}$ Bukša ističe da su na samim počecima pisane hrvatske dječje književnosti „Prve [...] naše $\mathrm{knjige,} \mathrm{pisane} \mathrm{izričito} \mathrm{za}$ d je cu, bil e ab e c edari “ (razmak Juraj Bukša), tj. „abecedari i ostali priručnici za đake samostanskih škola, benediktinskih a kasnije i franjevačkih“" (101). Profesor Bukša je očito novootvoreni prostor u većoj satnici književnosti (s dodanom satnicom u petom razredu) popunio tematikom dječje književnosti za koju se vrlo dobro spremio.

\section{1.}

Zakonom o pedagoškim akademijama iz 1960. obrazovanje za poziv učitelja ne daje više učiteljska petogodišnja škola, već je potrebno završiti dvogodišnju višu školu to jest pedagošku akademiju, kao što stoji u knjižici Pedagoška akademija u izdanju Školske knjige (1962: 151):

Početkom školske godine 1961/62. započele su rad i izvršile upis redovnih i izvanrednih studenata pedagoške akademije u Dubrovniku, Čakovcu, Karlovcu, Osijeku, Pakracu, Puli, Sl. Brodu, Splitu, Šibeniku, Zadru i Zagrebu. Pedagoška akademija u Rijeci osnovana je i započela rad u školskoj godini 1960/61, a u ovoj godini preseljenjem u novi prostor znatno proširuje svoju djelatnost i upisuje drugu generaciju studenata. Pedagoška akademija u Petrinji ove godine upisuje samo izvanredne studente, a u Gospiću se vrše pripreme za otvaranje ove škole. Otvoreno je i započelo rad 13 pedagoških akademija u koje je upisano 1232 redovna i 1751 izvanredni student.

U Rijeci je Pedagoška akademija osnovana godinu dana ranije nego u drugim gradovima, to jest 1960. Stoga se, sa stajališta ovog rada, postavlja pitanje nije li Pedagoška akademija u Rijeci i godinu dana ranije no ostale akademije u svoj nastavni plan već uvela kolegij koji je u nazivu već imao termin dječja književnost.

Prema usmenom iskazu profesora Jože Skoka, prvi predavač dječje književnosti na Pedagoškoj akademiji u Zagrebu bio je prof. Josip Busija. Kako je te akademske godine 1961./62. bilo 13 akademija, bilo bi zanimljivo saznati i imena ostalih 12 predavača dječje književnosti.

Pedagoška akademija prema Zakonu ne obrazuje samo učitelje (od 1. do 4. razreda) već i predmetne nastavnike za više razrede osnovne škole (od 5. do 8 . razreda) (1960: 231):

${ }^{11}$ U članku se Bukša izrijekom suprotstavlja Simi Cuciću, no prešutno, zapravo, polemizira s Ljudevitom Krajačićem. 


\section{Član 12.}

Studij u pedagoškoj akademiji sastoji se od općeg i posebnog dijela studija.

Opći dio studija obuhvaća proučavanje društveno-ekonomskih i pedagoškopsiholoških nauka i njime se osigurava jedinstvena osnova za obrazovanje nastavnika osnovnih škola.

Posebnim dijelom studija studenti se usmjeravaju i osposobljavaju za izvođenje razredne, odnosno predmetne nastave.

Za izvođenje posebnog dijela studija u akademiji se organiziraju dva odsjeka: odsjek za spremanje nastavnika za razrednu nastavu i odsjek za spremanje nastavnika za predmetnu nastavu.

U okviru I. odsjeka (dakle, onih studenata koji se obrazuju za razrednu nastavu), unutar grupe predmeta posebnog dijela studija, jedan od kolegija naziva se Kultura usmenog i pismenog izraza s dječjom literaturom. ${ }^{12} \mathrm{Na}$ samom početku nastavnog programa kolegija istaknuto je (Pedagoška akademija, 1962: 59):

Mjesto i značenje dječje književnosti u okviru jugoslavenske književnosti. Književnost za djecu i odrasle. Umjetnička ljepota i životna istina izražena u književnim djelima kao snažno sredstvo odgoja. Tematika u književnim djelima za djecu od sedme do petnaeste godine.

Time je dječja književnost točno pozicionirana u odnosu na književnost općenito, estetiku i pedagogiju. Dječja književnost je dio književnosti za odrasle pa se sve promjene koje su postojale u književnosti za odrasle moraju odraziti te postojati i u književnosti za djecu. To će postati naročito vidljivo u daljnjoj razradi programa gdje prevladavaju termini 'romantizam', 'realizam', kao i ideološki naputci uobičajeni u kritici tog vremena odrasle književnosti: „Piščev odnos prema društvu svoga vremena. Istina o teškom životu djece u kapitalističkom društvu. Borba za bolji i sretniji život." (60)

Izučavat će se samo estetski najrelevantnija djela te se estetski manje vrijedna, a kulturno ili povijesno značajna djela, neće uzimati u obzir. Također, književnost nije ništa drugo do sredstvo u službi odgoja i treba je isključivo izučavati kao takvu.

Na kraju programa se pak kaže (60-61):

$\mathrm{Na}$ osnovu poznavanja dječje psihologije treba postaviti odnos između literature za djecu i odrasle. Krajnji cilj uvođenja djece i omladine u književnost kao jedno od područja umjetnosti ne smije biti samo didaktički, već treba da bude emotivno doživljavanje neposredne životne istine izražene najvišim umjetničkim sredstvima.

Osnovu za razumijevanje odnosa između dječje književnosti i one za odrasle davat će psihologija. Znači, da dječja književnost svoj raison d'etre nema iz nekih umjetničkih razloga (primjerice što bi pružala umjetničke postupke koji bi omogućavali da se izrazi i neki od najviših dometa ljudskoga duha), nego ga dobiva

${ }^{12}$ Nastavnim planom predviđeno je da taj kolegij u 1. i 2. semestru ima po dva sata, a u 3. i 4. semestru po jedan sat tjedno. Nastavni plan objavljen je 1962. u knjižici-brošuri Pedagoška akademija. 
isključivo zahvaljujući psihologiji. Također, taj krajnji cilj ne smije biti samo naučen već mora biti posve interioriziran da bismo umjetnost mogli doživljavati kao „neposrednu životnu istinu“ (61) i to samo kad nam se posreduje na najčistiji umjetnički način, to će reći kroz najviša umjetnička ostvarenja.

U sklop dječje i omladinske književnosti također se uvode djela koja danas nitko ne bi ni pomislio uvrstiti u dječju književnost (60):

Antologijski izbor pripovjedaka i romana iz jugoslavenske književnosti. Kovačić: Iz romana U registraturi (Djetinjstvo i školovanje I. Kičmanovića); Novak: Nezasitnost i bijeda; Iz velegradskog podzemlja; Kozarac: Tri dana kod sina; Lazarević: Sve će to narod pozlatiti; U dobri čas hajduci; Glišić: Prva Brazda; Glava šećera; Nazor: Kurir Loda; Šimunović: Duga; Alkar; Andrić: Priča o kmetu Simanu; Bife: Titanik; Nušić: iz Autobiografije; Kolar: Glavno da je kapa na glavi; Kočić: Kroz mećavu, Jablan; Krleža: Domobran Jambrek; Bitka kod Bistrice Lesne; Kaleb: Divota prašine.

Uvođenje ovih djela u kolegij dječje književnosti odjek je onih teorijskih shvaćanja koja tvrde da ne postoji nešto takovo kao što je zasebna dječja književnost, već postoji samo umjetnička književnost čije dijelove mogu razumjeti i djeca.

Također, dječja književnost se obrađuje, osim u ovom kolegiju za razrednu nastavu, i u kolegiju Metodika nastave hrvatskosrpskog jezika gdje se izrijekom kaže: „Uvođenje u književnost. Upotreba literature za djecu, dječjih i drugih časopisa te dnevne štampe“ (55). Dakle, sada tek, na studiju na pedagoškim akademijama, dječja književnost se proučava i iz metodičkog aspekta, ali i kao posve samostalna nastavna građa, pa stoga po prvi puta zadobiva svoj dio u posve samostalnom kolegiju: dio kolegija se bavi Kulturom usmenog i pismenog izraza..., a dio ...dječjom literaturom.

U članku „Književnost za djecu i dječja književnost“ iz 1972. Milica Buinac, profesorica na Pedagoškoj akademiji u Petrinji, u prvom dijelu rada terminološki razvrstava 'književnost za djecu' (književnost koju odrasli pišu za djecu) i 'dječju književnost' (književnost koju pišu djeca), potom ukazuje na početke književnosti za djecu, a u posljednjem dijelu rada govori o „Izvorima i dostignućima dječjeg izraza u riječi“.. Drugim riječima, ona zapravo piše zašto su se našli u istom kolegiju (dakle, Kultura usmenog i pismenog izraza s dječjom literaturom), s jedne strane, dječji usmeni i pismeni izraz, a s druge, dječja književnost. To su dvije strane iste stvari, odnosa djece i književnosti: djeca dolaze u dodir s književnošću bilo da je primaju bilo da je daju, bilo da je čitaju bilo da je izražavaju.

U drugom odsjeku na pedagoškim akademijama, gdje se školuju predmetni nastavnici pa onda, za nas relevantni, nastavnici tzv. 'hrvatskosrpskog jezika', nema posebnog kolegija namijenjenog dječjoj književnosti. Tek se dosta kriptično u nastavnom programu za Hrvatskosrpski jezik u uvodnom dijelu „Zadaci“, spominje dječja književnost (Pedagoška akademija, 1962: 64): 
Pri izrađivanju programa ovog predmeta [književnosti općenito, op. B. M.] napušten je princip historicizma, čija je pretjerana primjena redovno opterećivala program mnogobrojnim ličnostima i manje značajnim djelima. Iz oblasti književnosti studenti će se posebno orijentirati na upoznavanje dječje i omladinske literature (v. program Kultura usmenog i pismenog izraza s dječjom literaturom iz posebnog studija I. odsjeka), zatim na izučavanje elemenata govorne umjetnosti.

Težište izučavanja književnosti stavljeno je na izbor tekstova 19. i 20. stoljeća s osvrtom na najvrednija književna djela ranijih razdoblja.

Kažemo 'kriptično' zato jer se ne vidi gdje i kako bi se ubacilo izučavanje dječje književnosti u silno detaljan i obiman program kolegija Književnost.

\section{9.}

Prema nastavnom planu za pedagoške akademije (Nastavni planovi $i$ programi, 1969) studij je trajao četiri semestra. Student se mogao opredijeliti između studija razredne nastave (dakle, od 1. do 4. razreda) ili predmetnog studija kojeg od predmeta koji su se predavali u osmogodišnjoj školi od 5. do 8. razreda. Na pedagoškim akademijama bio je organiziran i Predškolski studij.

Dječja književnost se kao posebni kolegij predavala u okviru Studija razredne nastave $\mathrm{i}$ to po tri sata tjedno u prvom i u drugom ${ }^{13}$ semestru. ${ }^{14}$ Dječja književnost je, znači, sada samostalni kolegij, a Kultura usmenog i pismenog izraza je također odvojeni i posebni kolegij koji se predaje po dva sata tjedno u 1., 2. i 3. semestru. Dakle, sada je zbrojena satnica oba kolegija $(3+3)$ i $(2+2+2)$ dvostruko veća nego što je bila 1961. kada su ti sadržaji sačinjavali jedan isti kolegij Kultura usmenog i pismenog izraza s dječjom literaturom i kad je iznosila $(2+2+1+1=)$ 6 sati tijekom studija.

U predmetnom studiju Hrvatskosrpskog jezika Dječja književnost se predavala u jednopredmetnoj grupi treći i četvrti semestar $2+1$ (dva sata predavanja i jedan sat seminara tjedno). ${ }^{15} \mathrm{U}$ dvopredmetnoj ${ }^{16}$ grupi Dječja književnost se predavala samo četvrti semestar i to samo dva sata predavanja tjedno. ${ }^{17}$

${ }^{13}$ U Petrinji se kolegij Dječja književnost predavao u prva tri semestra po dva sata (Zbornik Pedagoške akademije u Petrinji 1962-1972 1972: 27).

${ }^{14}$ Posebni kolegij Filmska i radio-televizijska kultura predavala se dva sata u trećem i četvrtom semestru.

${ }^{15}$ Posebni kolegij Filmska i radio-televizijska kultura u trećem i četvrtom semestru 1+1 (jedan sat predavanja i jedan sat seminara).

${ }^{16}$ Znači, predmetni je studij Hrvatskosrpskog jezika mogao biti ili samo jednopredmetan ili, pak, dvopredmetan. Kao dvopredmetan mogao se kombinirati s bilo kojim drugim predmetom, primjerice: Zemljopisom, Matematikom, Domaćinstvom i sl.

${ }^{17}$ Nema kolegija Filmske i radio-televizijske kulture. 
U Predškolskom studiju Dječja književnost se predaje tri sata u prvom i drugom semestru. ${ }^{18}$

Postoje dva nastavna programa: jedan za razrednu nastavu i drugi za predmetnu nastavu 'hrvatskosrpskog' jezika (jednopredmetnu grupu) dok za dvopredmetnu grupu (u kojoj se održavaju samo dva sata kroz jedan semestar) nije posebno razrađen program. Također nije posebno razrađen nastavni program Dječje književnosti niti na Predškolskom studiju.

Usporedbom oba nastavna programa Dječje književnosti vidi se da su oni posve identični pa su čak i „Napomene uz program“ identične.

Sadržaj nastavnog programa kolegija Dječja književnost: nakon „Uvoda u proučavanje dječje književnosti“" slijede poglavlja formirana prema vrstama dječje književnosti („Slikovnica“, „Priča“, „Umjetnička priča“, „Dječja poezija“, itd.).

Naročito je rasvjetljujući ovaj ulomak iz „Napomena uz program“ (Nastavni planovi i programi, 1969: 62 i 118-119):

U realizaciji ovog programa težište ne treba da bude na povijesnim i bibliografskim podacima, nego na studioznom ulaženju u probleme (dijete i slikovnica, dijete i bajka, dijete i pustolovna književnost, dijete i basna itd.) zatim na analizi i vrednovanju literarnog opusa vrhunskih pisaca te na informiranju o prihvaćenosti pojedinih djela od strane najmlađe publike.

Drugim riječima, Dječja književnost se neće proučavati u njezinom totalitetu i povijesnom razvoju, već će joj se pristupati dijelom problemski kroz isključivo vrhunska estetska ostvarenja, a dijelom kao metodici, to jest u interakciji dječje književnosti i učenika. Također će se ispitivati recepcija dječje književnosti u razredu. ${ }^{19}$

Stoga kolegij dječje književnosti nije imao karakter osnovnog predmeta koji bi potom imao svoju metodiku, već je i sam bio neka vrsta metodike.

Razvojnost, povijesni princip naveden je doduše za neke dječje vrste kao priču i poeziju, ali je izostavljen za dječji roman. Naravno da se to onda odrazilo i u djelima poput Zalarovog Dječjeg romana u hrvatskoj književnosti (1978/1983), te u nizu drugih studija i antologija koje su dječji roman jednostavno shvatile kao manjeviše sinkronijsku pojavu unutar koje treba provesti razgraničavanje na podvrste.

\section{Zaključak}

Prije pedeset godina, dakle u listopadu 1961., kolegij iz dječje književnosti konačno je isplivao na površinu i pojavio se na stranicama indeksa studenata. No,

\footnotetext{
${ }^{18}$ Posebni kolegij Filmska i RTV kultura se predaje u četvrtom semestru četiri sata.

19 Što nije isto kao i djelovanje nekog djela dječje književnosti na individualnog dječjeg čitatelja.
} 
to mu pojavljivanje u javnosti sigurno nije zajamčilo zaštićenost od nesnalaženja, lutanja i posezanja u 'tuđa' područja (metodike prije svega).

Ovaj rad prikazuje postupno izranjanje akademskog interesa za bavljenje istraživanjem dječje književnosti u Hrvatskoj. Svakako će biti zanimljivo vidjeti ne samo prikaze ove problematike iz drugih kutova (možda iz točaka gledišta drugih hrvatskih sveučilišta) već i radove koji će nam pokazati trendove u znanstvenom bavljenju dječjom književnošću kako u stručnim tako i u sveučilišnim studijima.

\section{Popis literature:}

Belović Bernadzikowska, Jelica. 1897. „Naša omladinska literatura“. Školski vjesnik: stručni list zemaljske vlade za Bosnu i Hercegovinu 4 (Juli i august): 419-452. Pretisnuto kao separat. Zagreb: HKPZ.

Bezić, Krešimir. 2003. Učitelj u zemlji čudesa. Zagreb: Hrvatski pedagoško-književni zbor. Buinac, Milica. 1972. „Književnost za djecu i dječja književnost“. U: Zbornik Pedagoške akademije u Petrinji 1962-1972. Petrinja: Pedagoška akademija u Petrinji.

Bukša, Juraj. 1951. „O programu iz književnosti za učiteljske škole“. Pedagoški rad 6 (1): 41-43.

Bukša, Juraj. 1952. „Počeci naše dječje književnosti“. U Spomenica učiteljske škole u Petrinji, ur. Odbor za proslavu 90. godišnjice Učiteljske škole u Petrinji, 99-104.

Demarin, Josip. 1954. Povijest i razvitak viših pedagoških škola u Hrvatskoj. Zagreb: Pedagoško-književni zbor.

Filipović, Ivan. 1885. „O omladinskoj književnosti“. Književna smotra 3 (3): 2-7.

Gorki, Maksim. 1949. O literaturi. Beograd: Kultura.

Gorki, Maksim, A. Beljajev i B. Tauber. 1945. Dajte deci literaturu!. Beograd: Novo pokoljenje.

Hollindale, Peter. 1998. “A Place for Children's Literature in English Literature." The European English Messenger 7 (2): 40-43.

Kobali, Milan. 1893. Rukovođ za estetičko-etična štiva u pučkoj školi. Zagreb: Hrvatski pedagogijsko-književni zbor.

Krajačić, Ljudevit. 1946. „Omladinska knjiga i njeni današnji zadaci.“ Narodna prosvjeta 2 (8-9): 9-13.

Modec, Ljudevit. 1885. Povjestne crtice o Kraljevskoj preparandiji u Zagrebu. Zagreb: Tiskara „Narodnih novinah“.

Nastavni plan i program za Učiteljsku školu. 1952. Zagreb: Savjet za prosvjetu, nauku i kulturu NR Hrvatske.

Nastavni planovi i programi. 1969. Zagreb: Školska knjiga.

Pedagogijska enciklopedija. 1895-1906. Zagreb: HPKZ.

Pedagoška akademija. 1962. Zagreb: Školska knjiga.

Plan i program za stručno usavršavanje nastavnika osnovnih i opšteobrazovnih srednjih škola za godinu 1946/47. 1946.

Privremeni nastavni plan i programi za učiteljske škole u Kraljevini Jugoslaviji. 1931. Beograd: Ministarstvo prosvjete Kraljevine Jugoslavije.

Službeni glasnik Ministarstva nastave. 1941. 1 (8): 680-682.

Širola, Stjepan. 1896. „Naša omladinska književnost“. Škola 7 (1): 11-14 i 7 (2): 31-34. 
Težak, Stjepko. 1971. „Viša pedagoška škola i Pedagoška akademija u Zagrebu“. Pedagoška akademija Zagreb 1919-1969, ur. Stjepko Težak i Josip Markovac, 5-7. Zagreb: Pedagoška akademija.

Ustrojni Štatut za učiteljske škole u Kraljevinah Hrvatskoj i Slavoniji. 1889. Zagreb.

Viša pedagoška škola u Zagrebu (osnovana 1919): Život i rad od početaka zavoda i sadašnje uređenje u 15 školskoj godini. 1934. Zagreb.

Zakon o pedagoškim akademijama. 1960. Prosvjetni vjesnik 13 (10).

Zalar, Ivo. 1978/1983. Dječji roman u hrvatskoj književnosti. Zagreb: Školska knjiga.

Zbornik Pedagoške akademije u Petrinji 1962-1972. 1972. Petrinja: Pedagoška akademija.

\section{Berislav Majhut}

University of Zagreb, Faculty of Teacher Education, Division in Petrinja

Zagreber Universität, Fakultät für Lehrerbildung, Abteilung Petrinja

\section{Fifty Years in Curricula: The First Croatian Course in Children's Literature}

The studying of literary techniques and methods in children's literature started in the late 19 th century, and the first accounts of the history of Croatian children's literature appeared in this period. However, the awareness that it is necessary to include the teaching of children's literature, based on the findings of scholarly research, into higher education curricula developed slowly. The paper describes the history of the process of gradual inclusion of children's literature as a topic in the higher education. The first courses including the study of children's literature appeared in teacher training institutions after WWII. The first course in which children's literature was included to a substantial extent, while the course name also contained the term "children's literature" was The Culture of Oral and Written Expression with Children's Literature. Such a course was delivered for the first time at Croatian teacher training colleges probably in 1961.

Keywords: children's literature course, Croatian children's literature, studying of children's literature, teaching of children's literature, teachers and children's literature

\section{Jahre im Vorlesungsverzeichnis. Das erste kroatische Kolleg über die Kinderliteratur}

Forschungsarbeiten zu kinderliterarischen Verfahren sowie Darstellungen der kroatischen Kinder- und Jugendliteratur gibt es in Kroatien seit Ende des 19. Jahrhunderts. Demgegenüber scheint sich das Bedürfnis nach einem auf diesen Ergebnissen aufbauenden Unterricht über die Kinderliteratur erst allmählich zu etablieren, und zwar erst nach dem Zweiten Weltkrieg an den Instituten für die Ausbildung von anstehenden Lehrern. Das erste Kolleg, dass sich derart mit dem Thema Kinderliteratur befasste, so dass der Begriff Kinderliteratur zum Bestandteil der Kollegbezeichnung wurde, war das Kolleg Mündliche und schriftliche Ausdrucksformen samt Kinderliteratur. Dieses Kolleg wurde erstmals an kroatischen Pädagogischen Akademien im Herbst 1961 vorgetragen.

Schlüsselwörter: kinderliterarisches Kolleg, kroatische Kinderliteratur, Studium der Kinderliteratur, Lehren von Kinderliteratur, Lehrer und Kinderliteratur 